\title{
The Differential Object Marking of The Arborense Dialect of Sardinian in Language Contact Setting
}

\author{
Daniela Boeddu \\ Department of Classical Studies, Faculty of Arts, University of the Basque \\ Country, Vitoria-Gasteiz, Spain \\ danielaboeddu@gmail.com
}

\begin{abstract}
This paper focuses on the Arborense Differential Object Marking (DOM) system, which in line with the typical Sardinian DOM system marks the object noun phrases characterized by a high degree of animacy and specificity with the preposition a. This is why the Sardinian Dом is also called prepositional accusative. Authors dealing with other Sardinian dialects agree in identifying three domains of distribution of the phenomenon: with personal pronouns and personal names the use of the preposition is mandatory; with inanimate common nouns it is excluded; with common nouns referring animate beings, strong variability occurs. On the basis of an oral corpus of contemporary Arborense, it can be stated that the area of mandatory use of DOM is restricted in this dialect and that the optionality area turns out to be more extensive than assumed in traditional descriptions of this Sardinian phenomenon. Since all the Arborense speakers of the oral corpus are bilingual (Sardinian-Italian), the data reflect the situation of DOM in a contact setting scenario where Sardinian and both Standard and Regional Italian interact. According to Putzu (2005) and Blasco Ferrer and Ingrassia (2010), the extensive area of optionality for the use of the Sardinian DOM should be the result of the influence of Standard Italian. However, two facts must be considered that make this idea questionable: first, in the language contact scenario of Modern Sardinian not only Standard Italian but also Regional Italian (with a widespread use of the DOM) play a role; second, the synchronic variation observed in contemporary Arborense replicates the same variation which characterizes historical data from texts of the 12th-19th centuries.
\end{abstract}




\section{Keywords}

Differential Object Marking - Language Contact - Sardinian - Arborense Dialect Regional Italian - Standard Italian

\section{Introduction}

This paper focuses on Differential Object Marking (DOM) in Arborense, a Sardinian dialect which is spoken in central-western Sardinia, in the territory of the province of Oristano.

The aim of this study is twofold. First I will offer a more complete view of the phenomenon involved by giving data of DOM in Arborense, a Sardinian dialect for which there was hitherto no study on prepositional accusative. In particular, I will inspect the situation of the DOM in this dialect according to an oral corpus. Second, I will observe inter-dialectal and infra-dialectal variation by comparing the distribution of the DOM as it is observed in the oral corpus with that of other Sardinian varieties, as well as with the results of a larger diachronic corpus in which the Sardinian DOM is analyzed from the beginning of the historical records of this language up to the present moment. I use the results of this investigation in order to discuss a problem associated with the interpretation of Putzu (2005) and Blasco Ferrer and Ingrassia (2010), who suggest that the variability of DOM in Modern Sardinian reflects the influence of Sardinian - Italian contact setting.

The paper is structured as follows. After a brief presentation of Sardinian in Section 1.1, in Section 1.2 I survey the existing literature on Sardinian DOM, and give an outline of the proposed distributional accounts of the phenomenon. In Section 1.3 I offer a description of DOM in Standard and Regional Italian. In Section 2, I lay out the methodological criteria according to which the data of the corpora were collected, classified and analysed. Section 3 offers the results of the study on the diachronic corpus and Section 4 presents the results of the analysis of the distribution of DOM in Modern Arborense. Section 5 compares the results of the two previous sections, and Section 6 discusses some issues concerning Sardinian DOM in the contact setting scenario in which Standard Italian and Regional Italian are considered. In Section 7 I summarize the main results of the investigation.

\subsection{The Sardinian Language}

Sardinian is a Romance language which is first attested in the $11^{\text {th }}$ century in the island of Sardinia, in the western Mediterranean Sea. Nowadays, it is used 
by around one million (generally Italian-Sardinian bilingual) speakers, in a situation of diglossia. Usually, Sardinian is mainly used in familiar and informal environments, whereas Italian is mainly spoken in the public sphere and is used for formal and written communication. There are two varieties of Italian:Standard Italian and Regional Italian (see Section 1.3). According to a study commissioned by the Regione Autonoma della Sardegna in 2006 (Oppo 2006), there are approximately one and a half million people that understand Sardinian and about one million people that are able to speak it.

Regarding its legal status, in the nineties of the last century Sardinian became a co-official language, alongside of Italian.

The Sardinian language is characterized by dialectal diversity. According to Virdis (1988), we can distinguish four main varieties: Campidanian in the South, Logudorian in the North, Nuorese in the East and Arborense in the West ${ }^{1}$. Among the four dialects there are characteristic differences especially in regard to phonology and morphology, and even within the same dialect there is a considerable degree of variation. ${ }^{2}$ In the course of its history, Sardinian has been in contact with a number of languages. In the $14^{\text {th }}$ century, the Kingdom of Sardinia was under the Catalan rule and, in the 16th century, the Island became a part of the Spanish empire. In the $18^{\text {th }}$ century, Sardinia passed to the House of Savoy and, later, it became part of the Kingdom of Italy. As a consequence, Sardinian has been in contact with Catalan and Spanish from the $14^{\text {th }}$ to the $18^{\text {th }}$ centuries and with Italian especially in the $19^{\text {th }}$ and in the $20^{\text {th }}$ centuries.

1 In the north coast of the island, there are two Italian varieties: Gallurese, which is a variety of Southern Corsican, and Sassarese, which evolved during the Middle Ages as a result of the contact between the native Sardinian population and groups of merchants and artisans that came from Pisa. On top of that, two further languages are still used in Sardinia: one is Catalan, spoken in the city of L'Alguer (S'Alighera in Sardinian and Alghero in Italian) on the north-western coast, and the other is Tabarchino, a Ligurian variety spoken in two small islands in the south of the main island.

2 For an overview of diatopic variation in Sardinian phonetics, morphology, syntax and vocabulary see Virdis (1988: 897-913), where an exhaustive bibliography is also added. See also Jones (1998) for an overview of phonetic, morphological, syntactic and lexical issues, and in particular Jones (1998: 314-16) for a brief state-of-the-art of Sardinian diatopic and diachronic variation. On the situation of Catalan and Spanish in Sardinia see Wagner (1922). Dettori (1998) presents a history of the language policies that have affected Sardinian before and after the political unification of Italy (XIX-XX centuries). Dettori (1993) reviews the literature about the Sardinian language, including grammars and dictionaries (XIX-XX centuries). In Dettori (2003) the reader may find a general description of Sardinian, including references to its external history, diatopic variation. For a criticism of the traditional view of the Sardinian language based on the opposition between innovative and conservative areas, see Bolognesi (2001) and Bolognesi and Heeringa (2005). For a brief survey of typological approaches to Sardinian see Putzu (2005a). 


\subsection{The Sardinian DOM}

The Sardinian Dom system, i.e. the use of the preposition $a$ before the object $\mathrm{NP}$, is determined mainly by two features of this NP: on the one hand, animacy, on the other, definiteness and specificity. Other factors related to sentential and textual organization (namely, dislocation of the object and clitic doubling) play a role as well.

Sardinian most probably developed Dом independently from other languages: in fact, the $11^{\text {th }}$ century Sardinian documents already show this feature. This DOM system is similar to that of other Romance languages such as Spanish (Pensado 1995; Fiorentino 2003; Mardale 2008, 2010), where the preposition $a$ also serves as the marker of the Dom. ${ }^{3}$

Regarding prepositional accusative, the Sardinian varieties which hitherto have been paid special attention are the Nuorese (Jones 1995, Putzu 2005), Campidanian (Blasco Ferrer 1998, Putzu 2005) and Logudorian (Putzu 2005) dialects. Authors dealing with different Sardinian dialects agree in identifying three domains of distribution of the preposition: (i) a domain where the preposition is mandatory (1st, 2nd, 3rd personal pronouns and proper names referring to animate beings, as shown in example (1a)); (ii) a domain where the preposition is excluded (inanimate common nouns, as in example ( $1 \mathrm{~b})$ ); and (iii) a domain within which variability occurs (common nouns referring to animate beings, as in example (1c), where the preposition $a$ between parentheses means the possibility of omitting the preposition). See also Table 5 for a picture of the diatopic variation of the Sardinian prepositional accusative.

(1) Arborense (personal knowledge)

$\begin{array}{llll}\text { a. Zuanne biet } & a & \text { Maria } \\ \text { PN } & \text { see.PRS.3SG } & \text { ACC } & \text { PN } \\ \text { 'John sees Mary.' } & & \end{array}$

$\begin{array}{lllll}\text { b. Zuanne } & \text { biet } & \emptyset & \text { sa } & \text { perda } \\ \text { PN } & \text { see.PRS.3SG } & & \text { DEF.F.SG } & \text { stone(F)-SG }\end{array}$

'John sees the stone.'
c. Seo
cricande
(a) unu
dotore
be.PRS.1SG search.GERUND
(ACC) INDF.M.SG
doctor(M)-SG
'I'm looking for a doctor.'

3 Some scholars, however, have argued that this similarity is only superficial. In Spanish and Rumanian, for instance, DOM seems to be conditioned primarily by semantic factors such as animacy and specificity (Mardale 2008, 2010). The optional cases of Sardinian Dом can also be accounted for on the basis of semantic factors (Mardale 2008, 2010). On the contrary, Jones $(1993,1995,1999)$ contends that the obligatory cases of DOM in Sardinian are conditioned 
In example (1c) the presence or absence of the preposition $a$ correlates with a change in meaning. If the indefinite object is preceded by the preposition $a$, it can only be interpreted as specific; if the indefinite object is not marked with the preposition, then it could be interpreted as specific or non-specific, depending on the context. There is agreement in that, definite human/animate direct objects are marked with the preposition $a$ only if they have a specific referent (Blasco Ferrer 1988; Floricic 2003; Putzu 2005). In the Campidanian example (2), the singular form omini refers to the totality of human beings, it therefore has not a specific reading. The presence of the preposition $a$ before omini would imply a specific man.

(2) Campidanian (Putzu, 2005: 241, ex. 55)

$\begin{array}{lllll}\text { Esti Deus chi adi fatu } & \emptyset s^{\prime} & \text { omini } \\ \text { be.PRS.1SG God } & \text { REL AUX.PRS.3SG make.PST.PTCP } & \text { DEF.M.SG man(M)-SG } \\ \text { 'It is God who created the Man.' } & & \end{array}$

According to various descriptions on the Sardinian prepositional accusative, this domain (common nouns referring to animate beings) is characterized by strong inter-dialectal and intra-dialectal variability, and some dialects are more permissive than others in admitting the use of the preposition. In the Nuorese variety, definite human direct objects tend to occur without prepositional accusative irrespective of their specificity. Note, in this sense, that Jones (1995) and Putzu (2005) provide different data regarding the variety of Lula, i.e. examples $(3 \mathrm{~b})$ and $(3 \mathrm{a})$ respectively. On the contrary, Logudorian and Campidanian show a wider use of the prepositional accusative with the same type of NP; see, for this question, Putzu (2005), Blasco Ferrer and Ingrassia (2010).

The examples in (3) illustrate this variation in the Sardinian prepositional accusative, as it appears from studies conducted so far by various researchers. In these examples the preposition $a$ between parentheses means the possibility of omitting the preposition.

(3) a. Nuorese, Fonni (Putzu, 2005: 235, ex. 27)

$\begin{array}{lllll}\text { Apo } & \text { vidu } & \emptyset & \text { su } & \text { dotore } \\ \text { AUX.PRS.1SG } & \text { see.PST.PTCP } & & \text { DEF.M.SG } & \text { doctor(M)-SG }\end{array}$

'I have seen the doctor.'

primarily by structure (in a nutshell, $a$ must be inserted before any definite object NP which lacks a determiner) and that the correlation with animacy is mediated by a categorial distinction (Noun vs Determiner) for various pronoun-like items (bare demonstratives and quantifiers, negative and interrogative pronouns). It is further argued that this categorial distinction is justified by other syntactic differences, not only in Sardinian but also in French (see especially Jones 1999). 
b. Nuorese, Lula-Bitti (Jones, 1995)

$\begin{array}{lllll}\text { Apo } & \text { vistu } & (a) & \text { su } & \text { dutore } \\ \text { AUX.PRS.1SG } & \text { see.PST.PTCP } & (\mathrm{ACC}) & \text { DEF.M.SG } & \text { doctor(M)-SG }\end{array}$

'I have seen the doctor.'

c. Logudorian, Marghine (Putzu, 2005: 235, ex. 28)

$\begin{array}{lllll}\text { Apo } & i d u & (a) & s u & \text { dotore } \\ \text { AUX.PRS.1SG } & \text { see.PST.PTCP } & \text { (ACC) } & \text { DEF.M.SG } & \text { doctor(M)-SG }\end{array}$

'I have seen the doctor.'

d. Campidanian (Putzu, 2005: 235. ex. 29)

$\begin{array}{llll}\text { Apu } & \text { biu } & \text { (as)-su } & \text { dotori } \\ \text { AUX.PRS.1SG } & \text { see.PST.PTCP } & \text { (ACC)-DEF.M.SG } & \text { doctor(M)-SG }\end{array}$

'I have seen the doctor.'

It is worth noting that, in a work on the Campidanian variety of Ogliastra, Blasco Ferrer (1988) underlines the key role of specificity for the prepositional accusative with definite NPs. However, Blasco Ferrer and Ingrassia (2010) present some cases from Campidanian (example 4a) and Logudorian (example 4b) in which non-specific definite objects can bear the preposition $a$, although oscillation is admitted and both examples (4a) and (4b) would also result grammatical without preposition.

(4) a. Campidanian (Blasco Ferrer and Ingrassia, 2010: 147, ex. 5)

Ma cástia, custu cardamponi béciu, est castiendi

Well look.IMP.2SG this tendon(M)-SG old(M)-s, be.PRs.1SG looking.GERUND

$\begin{array}{llll}\text { ancora } & (a) & \text { is } & \text { piciocheddas! } \\ \text { still } & \text { (ACC) } & \text { DEF.F.PL } & \text { girls(F)-PL }\end{array}$

'Well, look at this old man, who still looks at the girls!'

b. Logudorian (Blasco Ferrer and Ingrassia, 2010: 147, ex. 5)
Soe
cricande
(a) sos
cassadores
be.PRS.1SG looking for.GERUND
(ACC) DEF.M.PL hunters(M)-PL
$\begin{array}{lll}\text { de } & \text { cassa } & \text { manna } \\ \text { of } & \text { game(F)-SG } & \text { big(F)-SG }\end{array}$
I'm looking for big game hunters.'

In order to partially explain the strong inter-dialectal and intra-dialectal variation, Putzu (2008) and Blasco Ferrer and Ingrassia (2010) appeal to Italian 
influence on Sardinian. In particular, Putzu (2008: 409) suggests that oscillations in the use of prepositional accusative are probably due, among other causes, to the lack of a Standard Sardinian and to interferences of Standard Italian. Blasco Ferrer and Ingrassia (2010: 146), on their behalf, affirm that the influence of Standard Italian significantly altered the use of the prepositional accusative in younger generations, as well as in middle-aged people (much more in men than in women). In terms of Language Contact, the assumption of the interference of Standard Italian on the Sardinian prepositional accusative, i.e. the absence of prepositional accusative with object NP that in Sardinian are expected to bear the preposition, could be interpreted in a Maintenance/Borrowing scenario. 'Borrowing' is intended as the incorporation of foreign features (in this case, no preposition with object NPs) into a group's native language (Sardinian) by speakers of that language. 'Maintenance' means that the native language (Sardinian in this case) is maintained but it is changed by the addition of the incorporated features (cf. Thomason and Kaufman 1988: 37). Some issues arising from this interpretation are discussed in Section 6.

\subsection{The prepositional accusative in Standard Italian and Regional Sardinian Italian}

Although Standard Italian has been traditionally considered a language without DOM, in the last three decades some studies have detected prepositional accusative also in Standard Italian (Berretta 1989; Iemmolo 2010). According to these studies, Standard Italian has a minimally developed Dом according to which the preposition $a$ regularly appears with (especially first and second person) left-dislocated pronominal objects, which may have a resumptive pronoun within the clause. Consider the examples in (5).

(5) a. Standard Italian (Iemmolo, 2010: 249, ex. 6)

$\begin{array}{lllll}\text { A } & \text { me, non } & (m i) & \text { convince } & \text { questo } \\ \text { ACC 1SG.ACC NEG } & \text { CL.ACC.1SG } & \text { convince.PRS.3SG } & \text { this } \\ \text { 'This does not convince me.' } & & \end{array}$

b. Standard Italian (Iemmolo, 2010: 249 ex.9)

$\begin{array}{llllll}\text { A } & \text { te, } & \text { non } & \text { ti } & \text { sopporto } & \text { più } \\ \text { ACC } & \text { 2SG.ACC } & \text { NEG } & \text { CL.ACC.2SG } & \text { tolerate.PRS.1SG } & \text { more }\end{array}$

'I cannot stand you any longer.'

In addition to this, the variety of Regional Italian emerged in Sardinia in the $2^{\text {th }}$ century developed its DoM due to the influence of the Sardinian language (Loi Corvetto 1983). 
The Regional Italian of Sardinia can be defined as a linguistic continuum that goes from an imperfect form of (Standard) Italian acquired by native speakers of Sardinian to a colloquial register of Italian used by Sardinians who only have a passive competence of Sardinian. The Regional Italian of Sardinia is characterized by several features due to the influence of Sardinian, one of which is the prepositional accusative. In this study we only consider the type of Regional Italian which is widespread and accepted in every area of the island at all social levels 4 . It is spoken by both bilingual (Italian-Sardinian) speakers and Italian speakers (Loi Corvetto 1983). The relevant point at this moment is that the Dом system of the Regional Italian spoken in Sardinia is similar to the Dом system shown by Sardinian varieties (Putzu 2008). The Regional Italian examples (6) show that the use of the preposition can be found with human personal pronouns as well as with animate (not human) common nouns. There is, however, a difference between the two categories: personal pronouns seem to obligatorily present the preposition $a^{5}$, whereas the preposition is optional with animate (not human) common nouns. Note that (6b) presents $a$ with an indefinite animate (not human) NP, and on this specific example Putzu (2005) observes that the preposition is allowed by the presence of the relative sentence che abbaiava come un disperato 'which was barking desperately' that narrows the scope of the reference of the NP un cane. As a parallel case, the above example (1c) may be recalled, where the preposition $a$ is only acceptable if the referent of the NP is specific).

(6) a. Regional Italian (personal knowledge)

\begin{tabular}{|c|c|c|c|c|c|c|c|}
\hline Simone & ha & visto & $a$ & me & $e$ & $a$ & te \\
\hline $\mathrm{PN}$ & AUX.PRS.3SG & SEe.PST.PTCP & ACC & 1SG.ACC & and & ACC & 2SG.ACC \\
\hline
\end{tabular}

b. Regional Italian (Putzu 2005)

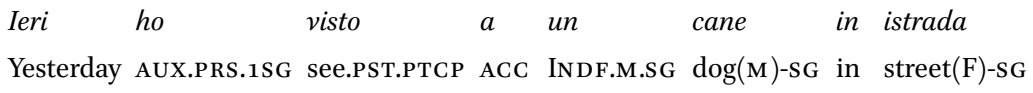

4 This widely socially accepted variety of Italian differs from other diastratically marked (and socially stigmatized) varieties of Italian spoken in Sardinia which derive from strong interference between Sardinian and Italian. This type of Italian is strongly oriented towards the dialect. It is used by Sardinian speakers that have little knowledge of Italian and who make frequent use of code switching to overcome their limited knowledge of Italian.

5 Since, as pointed out by an anonymous reviewer, the Regional variety of Italian spoken in Sardinia has no homogeneous and clearly defined grammar, it is certainly difficult to maintain that Dом is obligatory with personal pronouns or personal names in this variety, since any counterexamples can be treated as Standard Italian. 


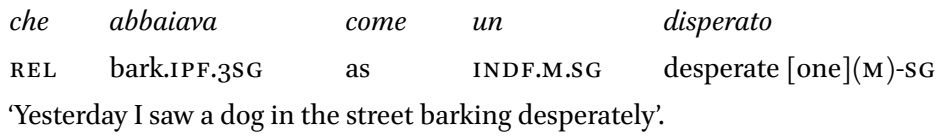

The presence of the prepositional accusative in the Regional Italian of Sardinia must be considered the outcome of a situation of language shift. In other words, the prepositional accusative of the Regional Italian of Sardinia is a substratum influence that results from group learning during a process of language shift. The deviation from the norm made by members of the shifting group in speaking Italian (in this case the introduction of the preposition $a$ with some object NPs) spread to Italian as a whole when they are imitated by new speakers of that language (cf. Thomason and Kaufman 1988: 39). Interestingly, the spreading of Dом in a language contact situation is attested also between languages with less genetic proximity than Sardinian and Italian. A case in point is the introduction of DOM in Maltese, a Western Arabic dialect, clearly due to the influence from Sicilian (a Romance dialect). Malta is approximately go kilometres from Sicily, and the two islands were part of the same political unit, the so-called Normal Kingdom of Sicily, from 1090 to 1530 . After that period, the two communities of speakers remained in close contact, and Sicilian influence on Maltese has been considerable. As a result of this influence, human definite direct objects are marked in Maltese with the indirect object marker, while inanimate objects receive no object marking. In the Maltese examples in (7), the ром is observed in the case of $(7 a)$, whereas the inanimate object in $(7 \mathrm{~b})$ has no such marking. These two examples are taken from Trudgill (2011: 47), who adduces the case of the Maltese DOM in his discussion on the acquisition of contact-induced complexity through the addition of a new morphological marker.

(7) Maltese (Trudgill, 2011:47)

a. Il-tifel ra li-l
DEF-boy saw to-DEF
'The boy saw Maria.'
b. Marija qabdet $\quad$ il-ballull.
PN caught DEF-ball
'Maria caught the ball.'

This is not the place to discuss the question on complexity dealt with by Trudgill. However, it is noteworthy that the socio-linguistic conditions stated by this scholar for this accretion of complexity are much the same as those found in the Sardinian case. 
The analysis on the Sardinian Dom carried through in this paper is based on two types of original data. On the one hand, we have a diachronic corpus of written Sardinian (Campidanian, Logudorian and Arborense varieties) resulting in 3121 human direct objects. On the other hand, we have an oral corpus of contemporary Arborense which has 216 instances of human direct objects.

The historical/diachronic corpus is composed by samples coming from nineteen texts and covers a period of eight centuries (XII-XIX). Diachronic studies on the Sardinian DOM, e.g. Putzu (2008), have hitherto investigated only medieval Sardinian. This corpus is heterogeneous from the point of view of the type of text: it includes patrimonial documents of monasteries, collections of laws, chronicles and poems of both secular and religious theme, translations of the Gospels and texts with a didactic purpose (Table 6).

Data on contemporary Arborense come from fourteen videotaped interviews of approximately thirty minutes each, where fourteen Sardinian native speakers talk about their life experience. These interviews are a part of a set of conversations entitled Memorie in lingua sarda ('Remembrances in Sardinian language') accessible on the website www.sardegnadigitallibrary.it. The group of speakers in the selected interviews is composed by seven men and seven women born between 1920 and 1940 whose mother tongue is Sardinian and who acquired Italian in their first years of life. The analysed interviews belong to persons coming from the Arborense area (i.e the villages of Bauladu, Bonarcado, Paulilatino, Ghilarza, Norbello, Abbasanta, Boroneddu, Tadasuni, Aidomaggiore, Sedilo, Noragugume, Nughedu Santa Vittoria, Ardauli, Busacchi).

These two corpora constitute the mayor piece of evidence in an investigation conducted by the present writer for a PhD thesis on Sardinian DOM (Boed$\mathrm{du}$, 2017). This doctoral research focuses on the diachronic development of Sardinian PREP.ACC, and tries to remedy the lack of corpus-based data for Sardinian. In the long run, it should constitute a preparatory work for the compilation of a larger Sardinian historical corpus.

In order to have a picture as complete as possible of the diachronic path of the Sardinian ром, it was also necessary to compare the results of the diachronic corpus with the present-day situation. For this reason, the preparation of an oral corpus of spoken Arborense is a way to provide data for prepositional accusative in contemporary Arborense dialect, for which no data was hitherto available. Several studies are available for the other three main Sardinian varieties (Campidanian, Logudorian and Nuorese dialects). The results offered in these studies on the other contemporary varieties of Sardinian are compared in this paper to the situation of the DOM as observed in the contemporary Arborense dialect. 
Data from both diachronic and syncronic corpora have been analysed according to the lexical category of the object NP (i.e. whether it is a personal pronoun, a proper name or a noun), on the one hand, and to its animacy and specificity, on the other. In this analysis, textual variables such as the position in the sentence of the object NP and the presence of clitic doubling have also been considered. Additionally, the data from the Arborense oral corpus have been compared to contemporary literary Arborense materials (see 'Contemporary Arborense litterary references' in the Appendix) and to data provided by other authors with respect to other diatopic varieties of Sardinian: the involved contributions are Jones (1995) and Putzu (2005) for the Nuorese dialect, Blasco Ferrer (1998) and Putzu (2005) for Campidanian, and Putzu (2005) for Logudorian ${ }^{6}$.

\section{Some Issues on the Diachrony of the Sardinian Prepositional Accusative}

As shown in Table 6 in the Appendix, the literary texts which compose the written diachronic corpus come from texts pertaining to a variety of dialect areas. Since this article is focused on dom in Arborense dialect, it is worth noting that two of the texts of the written diachronic corpus come from the Arborense area: The Condaghe of Santa Maria di Bonarcado (12th century) and The Carta de Logu (14th century). It is also important to notice that both texts show variability in the use of the preposition with animate objects, as it happens in the whole diachronic corpus. As illustrated in Tables 7 and 8 in the Appendix, the diachronic data reveals that, in the texts from the $15^{\text {th }}$ to the 19th century, the use of the prepositional accusative shows stability with personal pronouns and variability with personal names and other nominal categories with an animate referent, though it must be stated that personal names display a much lower degree of variability than common nouns.

As we will see in Section 4, the variation which characterizes diachronic data agrees with variation of the contemporary Arborense dialect. In fact, the Arborense dialect shows variation with both personal names and animate common nous, though it must be stated that the two categories show different degrees of variation, in the sense that common nouns display a much higher

6 The examples from the diachronic corpus are given as they appear in the corresponding edition. For the examples from the Arborense spoken corpus, I use the standardized orthography 'Limba Sarda Comune' adopted by the Regione Autonoma della Sardegna in 2006: http:// www.regione.sardegna.it/documenti/1_72_20060418160308.pdf; for the examples form the Contemporary Arborense literary materials I use the orthography that has been used by the authors of the novels. 
degree of variation than personal names. The fact that the present day situation of the Sardinian Dом maintains some features already present in the DOM of the past centuries suggests that the variation in the use of the prepositional accusative with personal names in the Arborense dialect and the variation with common nouns in almost all other Sardinian varieties are not 'new' characteristics of the DOM in contemporary Sardinian. This point will be examined more in detail in Section 4.

The following examples from the diachronic corpus show some personal names functioning as object without prepositional accusative.

(8) a. Sardinian (diachronic corpus, $15^{\text {th }}$ century, MTC, v. 328 )

Portande cum isse $\emptyset$ Januari Sanctu

Bring.GERUND with 3.M.SG Januar-PN Sanct(M)-SG

'Bringing Januari the saint with him.'

b. Sardinian (diachronic corpus, $17^{\text {th }}$ century, LVM, p. 8o)

$\begin{array}{lllll}\mathrm{Su} & \text { abade } & \text { clamadu } & \text { fra } & \text { Agapitu, } \\ \text { DEF.M.SG } & \text { abbot(M)-SG } & \text { call.PST.PTCP } & \text { friar(M)-SG } & \text { PN }\end{array}$

$\begin{array}{llllll}l i & \text { narat } & \text { qui } & \text { portaret } & \emptyset & \text { Panutiu } \\ \text { CL.DAT.3SG } & \text { tell.PRS.3SG } & \text { that } & \text { bring.sBJV.3SG } & & \text { PN }\end{array}$

as-sa cella de fra Smerallu

to-DEF.F.SG cell(F)-SG of friar(M)-SG PN

'The abbot, who is called friar Agapitu, tells him to bring Panutiu to the cell of Friar Smerallu.'

c. Sardinian (diachronic corpus, $18^{\text {th }}$ century, Carrus Pass., didascalia p. 81)

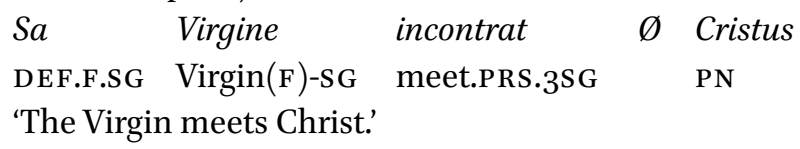

d. Sardinian (diachronic corpus, $19^{\text {th }}$ century, EvCamp., XXVI, 4)

$\begin{array}{llllll}E & \text { hianta } & \text { fattu } & \text { consillu } \\ \text { And } & \text { AUX.IPF.3.PL } & \text { made.PST.PTCP } & \text { meeting(m)-SG } \\ \text { po } & \text { arrestai } & \emptyset & \text { Gesus } & \text { a } & \text { tradimentu, } \\ \text { to } & \text { arrest.INF } & & \text { PN } & \text { by } & \text { surprise(F)-SG }\end{array}$




$$
\begin{array}{llll}
e & p o & d d u & \text { bocciri } \\
\text { and } & \text { to } & \text { CL.ACC.M.3SG } & \text { kill.INF }
\end{array}
$$

'And they had a meeting to arrest Jesus by surprise, and to kill him.'

Especially with respect to definite common nouns, the distribution of prepositional accusative depends partially on contextual factors. In general, in the literature on Sardinian prepositional accusative the preposition is admitted for common nouns, both definite and indefinite, provided that they are specific. Nevertheless, the diachronic corpus offers some cases in which such common noun objects are non-specific and are provided with the preposition, even though it is true that the use of the preposition in such cases is significantly less frequent than when the preposition is associated to specific objects. In some cases the referent of the prepositional object is quite generic but the reference scope is restricted by the presence of a possessive, as illustrated in example (9a), where a sa mulleri sua is interpreted as having a generic referent because the clause in which the NP is included states a general principle. On other occasions, the object NP has a generic referent but it occupies a relevant position in the clause, as in (9b), where the prepositional object $a$ sos demonios tuos infernales goes after a break in the intonation contour (signalized by the coma). The same happens in (9c) with $a$ is maridus, and in (9d) with $a$ unus fillus a unus sudditus. In example (9e), the object NP $a^{\prime}$ su malaventuradu appears in the text for the first time, but it is anticipated by a clitic $(d d u)$ and the intended referent has been already mentioned previously in the discourse (cussu señori miu 'that my lord').

(9) a. Sardinian (diachronic corpus, $19^{\text {th }}$ century, EvCamp, v, 31)

$\begin{array}{llll}\text { Esti } & \text { stetiu } & \text { nau } & \text { puru: } \\ \text { Be.AUX.IPF.3.SG } & \text { be.AUX.PST.PTCP } & \text { say.PST.PTCP } & \text { also }\end{array}$

$\begin{array}{lllll}\text { chini } & c i & \text { bogat } & a & s a \\ \text { the one who } & \text { here } & \text { Repudiates.PSR.3SG } & \text { ACC } & \text { DEF.F.SG }\end{array}$

$\begin{array}{llll}\text { mulleri } & \text { sua } & d d^{\prime} & \text { hat a donai } \\ \text { wife(F)-SG } & \text { POsS.F.3SG } & \text { CL.DAT.F.3SG } & \text { give.FUT.3SG }\end{array}$
$\emptyset \mathrm{su}$
libellu
de repudiu
DEF.M.SG document(M)-SG of repudiation(M)-SG

'It was also said: the one who repudiates his wife, he will give her the document of repudiation.' 
b. Sardinian (diachronic corpus, $15^{\text {th }}$ century, MTC v. 482-484).

$\begin{array}{llllrll}\text { Or } & \text { mira, } & \text { como, } & \text { quale } & \text { mengius } & \text { ti } & \text { paret,/ } \\ \text { Now } & \text { see.IMP.2SG } & \text { now } & \text { which [thing] better } & \text { CL.DAT.2SG } & \text { seem.PRS3SG }\end{array}$

$\begin{array}{lllllll}o & \text { adorare } & a & \text { Cristus, } & \text { qui } & \text { nos } & \text { at salvare,/ } \\ \text { either } & \text { venerate:IMF } & \text { ACC } & \text { PN } & \text { REL } & \text { 1PL } & \text { save:FUT.3SG }\end{array}$

$\begin{array}{llllll}o & a & \text { sos } & \text { demonios } & \text { tuos } & \text { infernales } \\ \text { or } & \text { ACC } & \text { DEF.M.PL } & \text { demons(M)-PL } & \text { POss.M.2PL } & \text { infernal(M)-PL }\end{array}$

'And now see, as you prefer, / either venerate Christ, who will save us,/ or your hell demons.'

c. Sardinian (diachronic corpus, $18^{\text {th }}$ century, Moriografia, pag. 51)

$\begin{array}{lllllll}\text { Si podeis cun custu, } & \text { assimbillai a cuddas } & \text { segnoras, } \\ \text { If can.PRs.2PL by this } & \text { resemble.INF to } & \text { those(F)-PL } & \text { ladies(F)-PL }\end{array}$

$\begin{array}{llllll}\text { chi } & \text { os } & \text { Apu celebrau, } & \text { Is qualis } & {[\ldots]} & \text { bestint } \\ \text { REL } & \text { CL.DAT.2PL } & \text { celebrate:PST.1SG } & \text { REL } & & \text { dress.PRS.3PL }\end{array}$

a sei e totu $e \quad a$ is maridus, $e$ adornant

ACC REFLEXIVE and ACC DEF.M.PL husbands(M)-PL and adorn.PrS.3PL

$\emptyset$ is palazius, e $\varnothing$ lettus insoru de seda

DEF.M.PL palaces(M)-PL and beds(M)-PL POss.3PL with silk(F)-SG

'Can you thus resemble to those ladies, about whom I spoke very well, who [...] dress themselves, and the husbands, and adorn palaces and their beds with silk?'

d. Sardinian (diachronic corpus, $18^{\text {th }}$ century, Moriografia, pag. 37)

Cunchè no tengu abbisongiu de rexonis fortis,

Therefore NEG have:PRS.1SG need(M)-SG of reasons(F)-PL strong(F)-PL

ne osi depu intimoriri comenta sudditus rebellus,

or CL.ACC.2PL have to.PRS1SG scare.INF as subjects(M)-PL rebellious(M)-PL

$e \quad$ Iscuntentus cun penas ni castigus,

and unhappy(M)-PL with penalties(F)-PL or punishments(M)-PL

a unus fillus a unus sudditus,

ACC INDF.M.PL children(M)-PL ACC INDF.M.PL SUBJECTS(M)-PL 
chi a sa suavidadi e benefizenzia reali sciu

REL to DEF.F.SG kindness(F)-SG and goodness(F)-SG royal(F)-SG know.PRS1SG

ch' inclinant a correspondiri con dozilidadi, e prontitudini. that will:PRS3PL to respond.INF with obedience(F)-SG and application(F)-SG 'Therefore I do not need strong reasons, or I do not have to scare you as rebellious subjects, and unhappy [subjects], with penalties and punishments, you children, you subjects, you that are willing to respond to the kindness and royal goodness with obedience and application.'

e. Sardinian (diachronic corpus, $17^{\text {th }}$ century, Esterzili, Conçueta del Nacimiento, v. 1106-1109).

Ittacasi c as tentadu/ ay cussu señori miu?/ What about that AUX.Prs.2SG tempt.PST.PTCP ACC that(M)-SG lord(M)-SG POss.M.1SG

$\begin{array}{llllll}\text { Mi } & \text { pesad } & c a & \text { no } & d d u & \text { biu/ } \\ \text { CL.DAT.1SG } & \text { weigh.PRS.3SG } & \text { that } & \text { NEG } & \text { CL.ACC.M.3SG } & \text { see.PRS.1SG }\end{array}$

$a^{\prime} \quad$ su malaventuradu

ACC DEF.F.SG unfortunate(M)-SG

'What? Have you tempted my lord? / I regret that I do not see him, / the unfortunate.'

As we can see in the previous examples, the preposition may be interpreted as a textual device to assign to the object a high level of individuation and / or a significant communicative relevance. From the Ancient Sardinian texts onwards the use of the preposition shows a high degree of flexibility in the domain of animate common nouns. In other words, the Sardinian prepositional accusative has maintained over the centuries a situation of constant or consistent instability. As we are going to see more in detail in the next sections, this situation is similar to that of contemporary Arborense, which roughly speaking displays the same degree of variability in the distribution of the preposition with non specific objects. It is worth pointing now that as for the affinity in the use of the prepositional accusative between contemporary Arborense and Sardinian as it appears in the diachronic corpus, the observations that we make in this article are based on comparisons between data coming from the diachronic corpus as a whole and data from spoken and written contemporary Arborense. The literary texts which compose the written diachronic corpus comes from a variety of dialect areas and two of them are written in Arborense dialect:The Condaghe of Santa Maria di Bonarcado (12th century) and La Carta de 
$\log u$ (14th century). These two text show variability in the use of the preposition with the animate object as it happens in the whole diachronic corpus.

\section{The Prepositional Accusative of the Contemporary Arborense Dialect}

This Section is devoted to present the data on the distribution of prepositional accusative in the contemporary Arborense dialect. Table 1 in the Appendix includes the object NPs of the oral corpus described in Section 2 above. Each row of the table corresponds to a type of NP and, for every type of NP, the first column indicates the percentage of the cases in which the object NP is marked with the preposition $a$, the second column indicates the percentage of nonprepositional objects, and the third column gives the total number of objects

TABLE 1 Arborense. Objects in canonical post-verbal position without pronominal duplication

\begin{tabular}{|c|c|c|c|}
\hline & $\mathbf{a}$ & $\emptyset$ & Total \\
\hline Personal pronouns & $8(100 \%)$ & o $(0 \%)$ & 8 \\
\hline Personal names & $5(41,67 \%)$ & $7(58,33 \%)$ & 12 \\
\hline $\begin{array}{l}\text { Kinship terms used as personal } \\
\text { names }\end{array}$ & $9(81,82 \%)$ & $2(18,18 \%)$ & 11 \\
\hline Definite common nouns & $3(4,84 \%)$ & $59(95,16 \%)$ & 62 \\
\hline Indefinite common nouns & $4(6,78 \%)$ & $55(93,22 \%)$ & 59 \\
\hline Pronominal demonstratives & $2(50 \%)$ & $2(50 \%)$ & 4 \\
\hline Adnominal demonstratives & $1(7,69 \%)$ & $12(92,31 \%)$ & 13 \\
\hline Adnominal universal quantifiers & $\mathrm{o}(\mathrm{o} \%)$ & $6(100 \%)$ & 6 \\
\hline Distributive universal quantifiers & - & - & - \\
\hline $\begin{array}{l}\text { Pronominal indefinite existential } \\
\text { quantifiers }\end{array}$ & $2(50 \%)$ & $2(50 \%)$ & 4 \\
\hline $\begin{array}{l}\text { Adnominal indefinite existential } \\
\text { quantifiers }\end{array}$ & $1(50 \%)$ & $1(50 \%)$ & 2 \\
\hline Pronominal negative quantifiers & $1(100 \%)$ & o $(0 \%)$ & 1 \\
\hline Interrogative quantifiers & - & - & - \\
\hline NPs with no lexical core & $\mathrm{o}(\mathrm{o} \%)$ & $1(100 \%)$ & 1 \\
\hline Total & $36(19,67 \%)$ & $147(80,33 \%)$ & 183 \\
\hline
\end{tabular}

Note: In this table, all the classes refer to animate entities. 
collected. Some types of NPs are not attested in the recorded material, and for these cases the corresponding cells of the table contain the symbol 'dash' (-). Recall that all the speakers of the Arborense oral corpus are Sardinian-Italian bilingual, so that the data reflect the use of Sardinian prepositional accusative in a contact setting scenario that includes Sardinian, Regional Italian and Standard Italian. As we can see in Table 1 and in example (10), the domain where the prepositional accusative is mandatory in contemporaneous Arborense is represented by 1st, 2nd and 3rd person pronouns: this type of NP is always introduced by the preposition $a$.

(10) Arborense, Bauladu (MarAtza, 18":55")

$\begin{array}{lllllll}\text { Tenio } & a & \text { issa } & e & \text { tenio } & \text { cussa } & \text { cumpannia. } \\ \text { Have.IPF.1SG } & \text { ACC } & \text { her } & \text { and } & \text { have.IPF.1SG } & \text { that(F)-SG } & \text { company(F)-SG }\end{array}$

'I had her and I had that company.'

All other human NPs constitute the domain where the preposition is admitted but not always used. Unlike other Sardinian varieties, Arborense shows variation with personal names, as it is shown in the examples (11). Example (11a) has prepositional accusative, whereas (11b-e) haven't; note that (11d,e) are examples coming not from the spoken corpus but from the two contemporary novels also quoted in Section 2 above. As illustrated in the examples (8), given in Section 3, personal names also show variability in the data from the diachronic corpus.

(11) a. Arborense, Bonarcado (Ang.Pi, 25':35")

Custu dd' iat nau ca cheriat a Pietrina

This CL.DAT.3SG AUX.IPF.3SG tell.PAST.PTCP that love.IPF.3SG ACC PN

'This told him that he loved Pietrina.'

b. Arborense, Busachi (GiFa, 21':40" $)^{7}$

A s' epoca che teniaus presidente $\emptyset$ Felicetto Contu.

At DEF.F.SG time(F)SG here have.IPF.1PL president(M)SG PN

'At that time we had Felicetto Contu as a president'.

7 An anonymous reviewer suggests that it is far from clear that Felicettu Contu is a direct object which would allow accusative $a$ and that the sentence is analogous to a reduced copular construction (cf. Su presidente fit ( ${ }^{*} a$ ) Felicettu Contu). Although this objection seems reasonable, there are cases in our data which have a similar construction and which crucially include the preposition $a$. One of these cases comes from the spoken contemporary Arborense corpus. It is the NP 'Santu Nicolau' in: Festa principale, nois tenimos a santu Nicolau chi 
c. Arborense, Aidomaggiore (GioBaPi, 21':oo")

$\begin{array}{llll}\text { Festamos } & \emptyset & \text { saint } & \text { Barbara } \\ \text { celebrate.IPF.1PL } & & \text { saint(F)SG } & \text { PN }\end{array}$

'We celebrate Saint Barbara.'

d. Arborense (Frau, p.37)

Andaiant fintzas a festare $\quad$ sos arcànzelos, $\emptyset$ santa Grega Go.IPF.3PL even to celebrate.INF DEF.M.PL archangels(M)PL Saint(F)SG PN

e $\varnothing$ sant' Àrbara de sos campos

and saint(F)SG PN of DEF.M.PL fields(M)PL

'They even went to celebrate the archangels, Saint Grega and Saint Barbara of the fields.'

e. Arborense (Arca, p. 142)

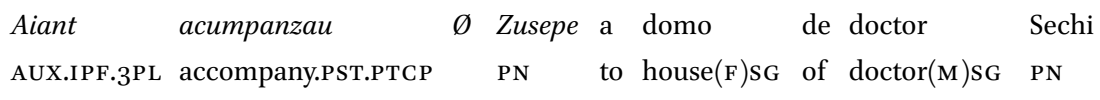

'They accompanied Joseph to the doctor Sechi's house.'

Arborense also shows variation with pronominal demonstratives, as it is shown in the examples (12). Example (12a) offers an instance of object demonstrative introduced by the preposition $a$ (i.e. $a$ custu), and (12b) has no such marker before custus. $^{8}$

(12) a. Arborense, Bonarcado (Ang.Pi, 27':10")

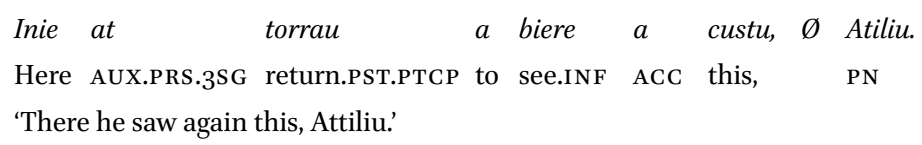

est su tres de dicembre 'As (the patron saint of) the main holiday, we have St. Nicolas, which is

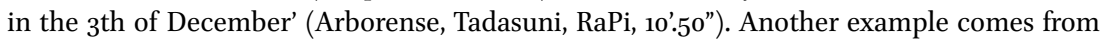
the diachronic written corpus and belongs to the Logudorian dialect. It is the personal name 'Herina' in: Istande eduncas Licinu imperatore in Macedonia, e tenende a Herina de amirabile bellesa, determinesit de fraigare una turre [...] e intro pongisit sa fija cun dodegui servas [...] e unu mastru pro la imparare clamadu Apellianu "Then, while the Emperor Licinius was in Macedonia, since he had Herina, [his daughter and because she was] of admirable beauty, he decided to build a tower, and he puts her daughter in the tower with twelve serves and a teacher called Apelliano" (1 $17^{\text {th }}$ century, LVM, p. 141).

8 Regarding other categories in the table, the small number of examples available does not allow for definite statements. 
b. Arborense, Sedilo (ToSa, 14':29")

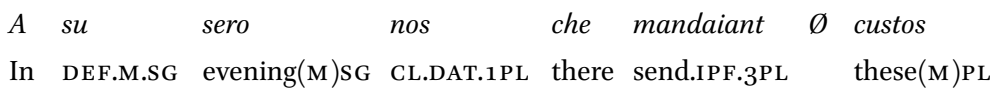

$i$ cumintziamos a ddos imparare a iscriere, a lezere. and start.IPF.1PL to CL.ACC.3PL teach.INF.1PL to write.INF to read.INF 'In the evening they sent us these [illiterate] and we start to teach them writing and reading'.

Table 1 and the examples in (11) and (12) include only syntactic structures in which the object NPs appear in the post-verbal position, i.e. the canonical position for verbal objects in Sardinian. As a further possibility, an object NP may appear in clause-initial position, and some of these cases have a resumptive clitic in the clause (Table 3), whereas some others do not (Table 2). The objects in clauseinitial position and with resumptive clitic as generally interpreted as cases of left dislocation, where 'dislocation' is intended as the 'placement of a constituent at the beginning or end of a sentence with resumptive pronominal element to indicate its grammatical function' (Jones 1995: 338, see also Lambrecht 2001: 1050$1051)^{9}$. Objects in clause-initial position without pronominal duplication in the clause or, as Jones (1995:338) puts it, the 'placement of a constituent in sentence-initial position without resumptive pronoun' are generally interpreted as cases of fronting. In the following example in (13) the direct object sas pitzocheddas 'the girls' is in the clause-initial position without resumptive clitic in the clause. This is an example of hanging topic, similar to the cases discussed in Blasco Ferrer and Ingrassia (2010) with regularly no overt markedness.

(13) Arborense, Bonarcado (Ang.Pi, 13':52")

$\emptyset$ Sas pitzocheddas chi fuint prus espertas, mandant cun DEF.F.PL girls(F)-PL REL be.IPF.3PL more expert(F)-PL send.IPF.3PL with

unu fozu iscritu a invitare $\emptyset$ totu sos familiares.

INDF.M.SG leaf(M)-SG write.PAST.PTCP to invite.INF all DEF.M.PL relatives(M)-PL 'The girls who were more expert, they sent them with a written message to invite all the relatives.'

In contrast to what can be observed in example (13), the examples in (14) include an object in clause-initial position with a correferential clitic in the clause. An object in clause-initial position with a correferential clitic in the

9 In Lambrecht $(1994,182)$ the left dislocations are also called detachment constructions and the dislocated position of the NPs is also called 'detached position'. 
Total

Definite common nouns

o $(0 \%)$

$1(100 \%)$

1

Indefinite common nouns

$\mathrm{o}(\mathrm{o} \%)$

$3(100 \%)$

3

Total

o $(\mathrm{o} \%)$

$4(100 \%)$

4

Note: In this table, all the classes refer to animate entities.

TABLE 3 Arborense. Objects in clause-initial position with pronominal duplication

\begin{tabular}{lrrr}
\hline & \multicolumn{1}{c}{ a } & \multicolumn{1}{c}{$\emptyset$} & Total \\
\hline Personal pronouns & $2(66,67 \%)$ & $1(33,33 \%)$ & 3 \\
Personal names & $1(50 \%)$ & $1(50 \%)$ & 2 \\
Kinship terms used as personal names & $3(100 \%)$ & $0(0 \%)$ & 3 \\
Definite common nouns & $0(0 \%)$ & $3(100 \%)$ & 3 \\
Pronominal demonstratives & $0(0 \%)$ & $1(100 \%)$ & 1 \\
Adnominal demonstratives & $0(0 \%)$ & $1(100 \%)$ & 1 \\
NPs with no lexical core & $0(0 \%)$ & $1(100 \%)$ & 1 \\
Total & $6(42,86 \%)$ & $8(57,14 \%)$ & 14 \\
\hline
\end{tabular}

Note: In this table, all the classes refer to animate entities.

clause could be interpreted as a left dislocated constituent. But we also should consider the possibility that the speaker has not decided on the syntactic structure of the comment at the point where the topic is introduced. In this case we could consider it as an hanging topic and it would not be expected any sort of case-marking on the topic (cf. Blasco Ferrer and Ingrassia 2010 and Jones 1993: 314-316).

In the Arborense dialect, this type of object (clause-initial objects with pronominal duplication) tends to appear without preposition, as illustrated in the Table 2 and in the examples (14a), (14c), and (14e). In this respect, this type of object tends to behave in the same way as the clause-initial objects without pronominal duplication exemplified in (13) (see Table 2). If we interpret them as left dislocated objects, the fact that, in Arborense, they tend to appear without preposition would be at variance with what is stated in the literature on Sardinian DOM, where both left and right dislocation of the object are viewed as favourable factors for the preposition (Jones 1995; Blasco Ferrer and Ingrassia 2010). Regarding the Nuorese dialect, Jones (1995: 44) notes that the object NPs that in a canonical phrasal context (svo) are obligatorily preceded by the 
preposition (i.e. personal pronouns and personal names), always present the preposition also when they are dislocated. On the contrary, the object NPs that in canonical svo context show oscillation (i.e. common nouns referring animates), tend to present the preposition more frequently in dislocation context than in canonical context.

Example (14a) from Arborense shows that the preposition $a$ can be absent even with clause-initial personal pronouns objects with pronominal duplication. The examples (14b) and (14c) show that clause-initial duplicated personal names appear either with preposition or without it respectively. Kinship terms referring to a relative of either the speaker or the addressee used without article, which behave as personal names, always present prepositional accusative, as shown in (14d). The remaining NP types always appear without preposition when they are clause-initial and duplicated. Example (14e) illustrates a case of a definite common noun. Note that sos enemigos is the object of the verb faiat. Example (14f) illustrates the case of a demonstrative pronoun.

(14) a. Arborense, Bauladu (MarAtza, o6':oo")

Pagus si portant a campagna a nosu.

Few CL.ACC.1PL take.IPF.3PL to countryside(F)-SG ACC 1PL

$\emptyset$ Nosu no si portant a campagna

$1 \mathrm{PL}$ NEG CL.ACC.1PL take.IPF.3PL to countryside(F)-SG

'They took us to the countryside few times. We, they did not take us to the countryside.'

b. Arborense, Bonarcado (Ang.Pi, 25':30")

$\begin{array}{llllll}\text { Inveze, } & a & \text { Pietrina } & d d^{\prime} & \text { aiat } & \text { connota } \\ \text { Instead } & \text { ACC } & \text { PN } & \text { CL.ACC.3SG } & \text { AUX.IPF.3SG meet.PST.PTCP }\end{array}$

currinde a caddu de $s^{\prime} \quad$ ainu.

ride.GERUND on back of DEF.M.SG donkey(M)-SG

'Instead, he met Pietrina the same way, when he was riding a donkey.'

c. Arborense, Nughedu (PieSca, o6':17")

$\emptyset$ Ventura, sa manna, si che $d$ '

PN DEF.F.SG older(F)-SG REFLEXIVE here CL.ACC.3SG

$\begin{array}{llll}\text { at } & \text { leada } & \text { una } & \text { tzia. } \\ \text { AUX.PRS.3SG } & \text { bring:PST.PTCP } & \text { INDF.F.SG } & \text { aunt(F)-SG }\end{array}$

'Ventura, the older one, the aunt took her away.' 
d. Arborense, Ardauli (MaCo, 24':42")

Presèmpiu, a mama mia dd' ant cantada

For example ACC mum(F)-SG POSS.F.1SG CL.ACC.3SG AUX.PRS.3PL sing:PST.PTCP

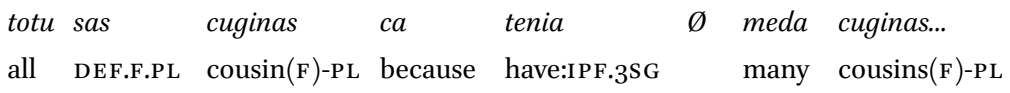

puru sa zente de su ghinau, sas amigas

also DEF.F.SG people(F)-SG of DEF.M.SG neighbourhood(M)-SG DEF.F.PL friends(F)-PL

$\begin{array}{lllll}\text { chi } & \text { tenia }, & a & \text { mama } & \text { mia } \\ \text { REL } & \text { have.IPF.3SG } & \text { ACC } & \text { mum(F)-SG } & \text { POSS.F.1SG }\end{array}$

dd' ant cantada meda.

CL.ACC.3SG AUX.PRS.3PL sing.PST.PTCP much

'For example, my mother, they all sang [= sang funeral songs to] her, all the cousins, because she had many cousins... also the people in the neighbourhood, the friends she had, my mother, they sang much to her'

e. Arborense, Tadasuni ( $\mathrm{RaPi}, 28$ ':30")

[Unu chi] cando fiat richiamau nant ca faiat semper...

One REL when be.IPF.3Sg call.PST.PTCP say:PRS.3PL that do.IPF.3SG always

$\emptyset$ sos enemigos, nant ca ddos punghiat semper

DEF.M.PL enemies(M)-PL say:PRS.3PL that CL.ACC.3SG prick.IPF.3SG always

in sa lancia, $s^{\prime} \quad$ isciabola, e che ddos

in DEF.F.SG spear(F)-SG DEF.F.SG sword(F)-SG and here CL.ACC.3PL

etiat a segus comentechi funtis panes de figumorisca

throw.IPF.3SG to back as if be.IPF.3PL leaves(M)-PL of pricklypear '[One who] when he was a soldier [litt.: when he was called to the arms] [people] say that he always did.... the enemies, he always pricked them with spear, the sword, and threw them back as leaves of prickly pear.'

f. Arborense, Boroneddu (GioPi, 19':39")
Apo
tentu
$\varnothing s u$
mascu.
$\emptyset \quad$ cussu $d d^{\prime}$
AUX.PRS.1SG have.PST.PTCP
DEF.M.SG boy(M)-SG this
CL.ACC.3SG 


apo tentu in su
AUX.PRS.1SG have.PST.PTCP in DEF.M.SG month(M)-SG of $\operatorname{march(M)-SG}$
'I had the [son] boy. This one, I had him in March.'

TABLE 4 Arborense. Objects in canonical post-verbal position with pronominal duplication

\begin{tabular}{lrrr}
\hline & \multicolumn{1}{c}{ a } & \multicolumn{1}{c}{$\emptyset$} & Total \\
\hline Personal pronouns & $3(100 \%)$ & $\mathrm{o}(\mathrm{o} \%)$ & 3 \\
Personal names & $2(100 \%)$ & $\mathrm{o}(\mathrm{o} \%)$ & 2 \\
Definite common nouns & $2(33,33 \%)$ & $4(66,67 \%)$ & 6 \\
NPs with no lexical core & $1(100 \%)$ & $\mathrm{o}(\mathrm{o} \%)$ & 1 \\
Pronominal universal quantifiers & $\mathrm{o}(\mathrm{o} \%)$ & $3(100 \%)$ & 3 \\
Total & $8(53,33 \%)$ & $7(46,67 \%)$ & 15 \\
\hline
\end{tabular}

Note: In this table, all the classes refer to animate entities.

As a further possibility considered in Table 4 and in examples (15a-d), a lexical object may appear in post-verbal position with a correferential clitic included in the clause. NPs in post verbal position which are anticipated by a clitic could be considered as cases of right dislocation. But it is not always easy to decide if a post verbal object anticipated by a clitic is a dislocated constituent. This is due to the fact that, normally, dislocated NPs are separated from the rest of the sentence by a break in the intonation contour and in right dislocations this effect is less marked and consequently less perceptible. More in general, in the case of a duplicated post verbal object, the preposition $a$ can be interpreted as a sign of the specificity of the referent of the NP in the context of the discourse. The examples in (15a) represent such a situation: the lexical object $a$ su poeta mannu 'the important poet' appearing at the very end of the quote, is not separated from the rest of the sentence by any break in the intonation contour and it is correferential with the pronoun $d d^{\prime}$ included in the verbal complexes $d d^{\prime} a t$ arrespostu 'replied at him' and dd'at cunvintu 'convinced him'; the lexical object is highly referential since it has been mentioned previously in the text. Similarly, in (15b) the referent of the NP is highly referential but, differently from (15a), in (15b) it is not easy to perceive the break in the intonation contour (note that Giuà is a vocative expression and has therefore a different referent than su pipiu). Finally, in $(15 \mathrm{c})$ the referent of the object is generic and any break is perceivable in the intonation contour.

In example (15d) a NP such as s'omine 'the man' is not expected to show preposition, because it has a generic referent (the speaker is describing a general situation). However, in this example, s'omine is connected with another NP 
previously mentioned and which has the same referent: su chi si praghiat 'the one we liked'. Note also the presence of $d u$, a masculine object personal pronoun referring to the NP su chi si praghiat 'the one we like' and sharing the same referent of s'omine 'the man'. Furthermore, s'omine is separated from the rest of the sentence by a little break in the intonation contour (represented here by a coma), hence it can be interpreted as a case of right dislocation. According to the literature on Sardinian DoM, dislocation facilitates the presence of the prepositional accusative (even if, as illustrated above, in our data left dislocation does not seem to favour in a special way the presence of the prepositional accusative).

(15) a. Arborense, Nughedu (PieSca, 22':40")

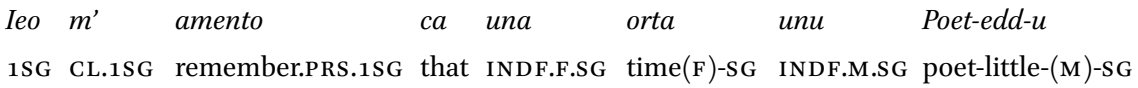

chi no fut mancu in gamba meda cun unu poeta

REL NEG be.IPF.3SG not even in leg(F)-SG much with INDF.M.SG poet(M)-SG

mannu, sa note dd' at arrespostu

important(M)-SG DEF.F.SG night(F)-SG CL.DAT.3SG AUX.PRS.3SG reply.PST.PTCP

quasi-quasi $d d^{\prime} \quad$ at cunvintu

almost CL.ACC.3SG AUX.PRS.3SG convince.PST.PTCP

$\begin{array}{llll}a & \text { su } & \text { poeta } & \text { mannu } \\ \text { ACC } & \text { DEF.M.SG } & \text { poet(M)-SG } & \text { important(M)-SG }\end{array}$

'I remember that once a little poet that was not so good, facing an important poet, that night [the little poet] replied at him, almost reached to convince him [of his ability], the important poet.'

b. Arborense, Norbello (MaOttCa, 26':40")

Lassa-ddu istare tranquillu... su pipiu, Giuà

Leave.IMP.2SG - CL.ACC.M.3SG be.INF alone(M)-SG DEF.M.SG child(M)-SG PN 'Leave the child alone, Giuà.'

c. Arborense, Ardauli (MaCo, 21':10")
In un'
istanza
ma però, po $d d u$
mirare andiant
In INDF.F.SG $\operatorname{room}(\mathrm{F})$-SG but but to CL.ACC.M.3SG see.INF go.IPF.3PL
a cuss' istanza sos familaires, $e$ sos amigos
to that(F)-SG room(F)-SG DEF.M.PL relatives(M)-PL and DEF.M.PL friends(M)-PL 
e sos ighinos, $d d u$ mirant in $s^{\prime}$ istanza and DEF.M.PL neighbours(M)-PL CL.ACC.M.3SG see.IPF.3PL in DEF.F.SG room(F)-SG
chi fiat
$\emptyset \quad s u$
mortu.
$D d u$
vegliant
REL be.IPF.3SG
DEF.M.SG $\operatorname{dead}(M)-S G$
CL.ACC.M.3SG
watch.IPF. $3^{\mathrm{PL}}$

\begin{tabular}{|c|c|c|c|c|c|c|}
\hline$s^{\prime}$ & istanza & chi & fiat & $\varnothing$ & su & mortu. \\
\hline the & room & REL & be.IPF 3.SG & & DEF.M.SG & $\operatorname{dead}(M)-S G$ \\
\hline
\end{tabular}

'In a room, however, to sow him they, the relatives, went to that room, and the friends, and the neighbours, they watched him in the room where the dead was. They had a wake for him in the room where the dead was.'

d. Arborense, Bonarcado (Ang.Pi, 17':20")

Cando faian sos ballos in sa partza, ddue fuit When do.IPF.3PL DEF.M.PL ball(M)-PL in DEF.F.SG square(F)-SG there be.IPF.3SG
$s^{\prime}$
omine chi beniat
a invitare
$\emptyset \quad s a$
femina $[\ldots]$
DEF.M.SG $\operatorname{man}(M)$-SG REL come.IPF.3SG to invite.INF
DEF.F.SG woman(F)-SG

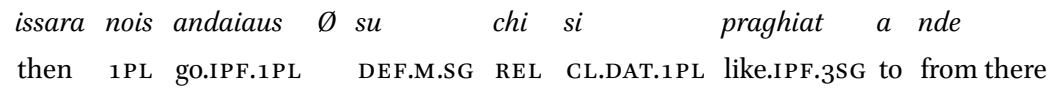

$\begin{array}{lllll}d d u & \text { tirare, } & a & s^{\prime} & \text { omine. } \\ \text { CL.ACC.M.3SG } & \text { take.INF } & \text { ACC } & \text { DEF.M.SG } & \operatorname{man}(\mathrm{M}) \text {-SG }\end{array}$

'When there was a ball in the square, there was the man who went to invite the woman $[. .$.$] then we went to take the one we like, the man.'$

Therefore, regarding the syntactic context in which prepositional accusative appears, we can make the following observations. First, as we can see in Table1, the preposition is infrequent $(19,67 \%)$ when the object appears in canonical post-verbal position without pronominal duplication, although it is worth noting that there is a difference in the percentage of use with personal pronouns, demonstrative pronouns and personal names and percentages of use with other NPs categories. Second, as it is shown in Tables 2 and in Table 3, the preposition is completely absent in case of clause-initial objects without pronominal duplication and it tend to not appear with clause-initial objects with pronominal duplication. In addition, it is important to say that in our data, the clause-initial objects without pronominal duplication are all common nouns, while among clause-initial objects with pronominal duplication also personal names appear, as e.g. Ventura in example (14c). Since ACC.PREP. most often 
occurs with personal names in canonical post-verbal position, if we consider the NP Ventura in (14c) as a case of left dislocation, the absence of the preposition in (14c) is a remarkable fact, since in the literature on Sardinian DOM both left and right dislocated object are viewed as good candidates for bearing the preposition (Jones 1995; Blasco Ferrer and Ingrassia 2010). Finally, on the contrary, as shown in Table 4 , the preposition is often added (53,33\%) to object NPs in post-verbal position with pronominal duplication.

In summary, the present day situation of the Sardinian DOM maintains some features already present in the DOM of the past centuries. In consequence, neither the variation in the use of the prepositional accusative with personal names in the Arborense dialect nor the same variation with common nouns in almost all Sardinian varieties can be taken as 'new' characteristics of the Dом in contemporary Sardinian.

The situation of the Arborense dialect is quite different from the situations described in previous research on other Sardinian varieties mentioned above in Section 1.2. For these varieties a certain degree of stability in the use is generally assumed, in the sense that in general non-specific direct objects (although definite) are viewed as not good candidates for the preposition. As said previously in section 1.2, only Blasco Ferrer and Ingrassia (2010) presents some cases from Campidanian and Logudorian in which non-specific definite direct objects bear the prepositional accusative. The difference between ром in the Arborense dialect and Dом in the other Sardinian varieties will be illustrated in Section 5 .

This section will offer some observations which result from the comparison of DOM as it appears in the data of the spoken corpus of Arborense just referred to, on the one hand, with the Dом as it is described in the literature on the other Sardinian varieties, on the other. Since previous descriptions are based on data of Campidanian, Logudorian and Nuorese, it seems reasonable to compare the findings based on these varieties with the Arborense data of the oral corpus described above.

The analysis of the oral corpus of contemporary Arborense reveals a situation which basically agrees with the general picture of the Sardinian Dом in which there are three general domains of distribution of the prepositional accusative. However, the limits of the three domains in contemporary Arborense are not the same as they appear in the previous descriptions of Sardinian prepositional accusative. Recall that, in these descriptions, the area of mandatory 
preposition involves both personal pronouns and personal names, the area of optional preposition involves specific common animate nouns, and the area in which the preposition is not allowed involves both non-specific animate and inanimate common nouns. Table 5 compares Arborense data to data from other dialects. The asterisk (*) in the table indicates that the data have been collected integrating data from Arborense spoken corpus and literary materials. Our data confirm the existence of the three distributional patterns mentioned above, i.e., (1) preposition obligatorily required, (2) preposition allowed but not obligatory, and (3) preposition not allowed at all. Nevertheless, the boundaries between these zones which can be observed in the Arborense data do not agree with those given in previous descriptions of the other Sardinian dialects. In the Arborense dialect, the area of mandatory preposition is restricted to personal pronouns, whereas the optionality area results more extensive than expected in the other Sardinian varieties. That is to say, Arborense shows variation in the noun classes that in the Campidanian, Logudorian and Nuorese varieties are considered as a part of the mandatory domain: in fact, personal names, which in the previous description are part of the mandatory preposition area, belong to the optionality area in Arborense data, even though they certainly show a strong tendency to be prepositional objects $(41,67 \%, 5$ of 12 NPs, as we can see in Table 1). In addition, pronominal demonstratives and quantifiers ${ }^{10}$ show oscillation in the use of Arborense speakers. The literary materials of contemporary Arborense (the two novels by Frau and Arca quoted in the Appendix) also reveal that NPs referring to both human and non-human animate beings are susceptible to receive prepositional accusative, though there is a considerable difference in the use of the preposition depending on the human or non-human character of the involved object.

Bearing those considerations in mind, we can note that the Arborense dialect differs from other varieties of Sardinian in that it allows the absence of $a$ with nominal classes that in other varieties are generally considered part of the domain of obligatory use of the preposition (Table 5). This fact is striking for two reasons: first, it shows that, at least in the Arborense dialect, the use of the prepositional accusative has a considerable flexibility; second, this flexibility in the contemporary use coincides with the variability of the diachronic data. These two facts are important for some claims concerning the contact setting that we are going to present in the next section.

10 Regarding interrogatives and negatives we can not say if the data (prepositional accusative obligatory required) reflects the reality of use, due the small number of cases in the materials. 
Arborense Campidanian Logudorian Nuorese

\section{Personal pronouns}

Personal names

Kinship terms used as

personal names a

$\mathrm{a} / \varnothing^{*}$

$\mathrm{a} / \varnothing$

$a / \varnothing^{*}$

$\mathrm{a} / \varnothing$

$\varnothing$

$\mathrm{a} / \varnothing$

Indefinite specific

common nouns

Indefinite no-specific

$\varnothing$

common nouns .

Pronominal

$\mathrm{a} / \varnothing^{*}$

a

$a / ø^{*}$

$\mathrm{a} / \varnothing$

a

Adnominal universal

$\emptyset$ *

quantifiers

Indefinite existential

$\mathrm{a} / \varnothing^{*}$

quantifiers

Distributive universal quantifiers

Negative quantifiers

Interrogative

quantifiers

\section{a}

a

a

$\mathrm{a} / \varnothing$

$\varnothing$

a

$a / \varnothing^{*} \quad a$

a $a / \varnothing$

$ø / a$

$a / \varnothing$ $\varnothing$

a

$\mathrm{a} / \varnothing$

a

a

a

a

\section{a}

a

a

a

$a / \varnothing$

$a / \varnothing$

$a / \varnothing$

$\varnothing / a$

$\varnothing$

$\mathrm{a} / \varnothing$

$\varnothing$

a

$\emptyset$

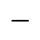

a

a

NPs with no lexical core a/ø*

${ }^{a}$ Only Blasco Ferrer and Ingrassia (2010) presents some cases from Campidanian and Logudorian in which non-specific definite direct objects bear the prepositional accusative (cf. Section1.2 of this article).

Note: In this table, all the classes refer to animate entities. 
TABLE 6 The prepositional accusative in the Sardinian diachronic corpus

\begin{tabular}{lllrrrrr}
\hline Dialect & Century & Text & a & & ø & & Total \\
\hline Arb & XII & CSMB & 282 & $(58,18 \%)$ & 202 & $(41,82 \%)$ & 484 \\
Log & XII & CSNT & 84 & $(41,79 \%)$ & 117 & $(58,21 \%)$ & 201 \\
Log & XII & CBossove & 16 & $(26,67 \%)$ & 44 & $(73,33 \%)$ & 60 \\
Log & XIII & LJT & 11 & $(22 \%)$ & 39 & $(78 \%)$ & 50 \\
Arb & XIV & CdL & 18 & $(14,88 \%)$ & 103 & $(85,12 \%)$ & 121 \\
Log & XV & RSorress & 40 & $(37,04 \%)$ & 68 & $(62,96 \%)$ & 108 \\
Log & XV & MTC & 31 & $(31,96 \%)$ & 66 & $(68,04 \%)$ & 97 \\
Log & XVI & CLuogosanto & 1 & $(20 \%)$ & 4 & $(80 \%)$ & 5 \\
Log & XVI & LoFrasso & 3 & $(50 \%)$ & 3 & $(50 \%)$ & 6 \\
Log & XVI & MTA & 34 & $(50 \%)$ & 34 & $(50 \%)$ & 68 \\
Log & XVII & LVM & 170 & $(33,33 \%)$ & 340 & $(66,67 \%)$ & 510 \\
Camp & XVII & Esterzili & 203 & $(63,24 \%)$ & 118 & $(36,76 \%)$ & 321 \\
Log & XVIII & CarrusPassione & 67 & $(51,15 \%)$ & 64 & $(48,85 \%)$ & 131 \\
Log & XVIII & Delogu Ibba Iscl & 53 & $(41,41 \%)$ & 75 & $(58,59 \%)$ & 128 \\
Log & XVIII & Sluxorio & 19 & $(26,39 \%)$ & 53 & $(73,61 \%)$ & 72 \\
Camp & XVIII & SuTesoru & 4 & $(7,84 \%)$ & 47 & $(92,16 \%)$ & 51 \\
Camp & XVIII & Moriografia & 9 & $(40,91 \%)$ & 13 & $(59,09 \%)$ & 22 \\
Log & XIX & EvLog & 99 & $(28,53 \%)$ & 248 & $(71,47 \%)$ & 347 \\
Camp & XIX & EvCamp & 129 & $(38,05 \%)$ & 210 & $(61,95 \%)$ & 339 \\
Total & & & 1273 & & 1848 & & 3121 \\
\hline & & & & & & \\
\hline
\end{tabular}

Note: In this table, all the classes refer to animate entities. Setting Scenario

As mentioned at the outset, some scholars have argued that Standard Italian plays a role in the variation (in the sense of diminution) of Sardinian prepositional accusative and that the optionality area may be the result of Italian influence (Putzu 2005; Blasco Ferrer and Ingrassia 2010). Indeed, Putzu (2008:409) and Blasco Ferrer and Ingrassia (2010:146) appeal to Italian influence on Sardinian to partially explain the strong inter- and infra-dialectal variation, suggesting that oscillations in the use of prepositional accusative are probably due, among other causes, to the influence of Standard Italian. In view of what has been observed in the previous sections on the Sardinian 


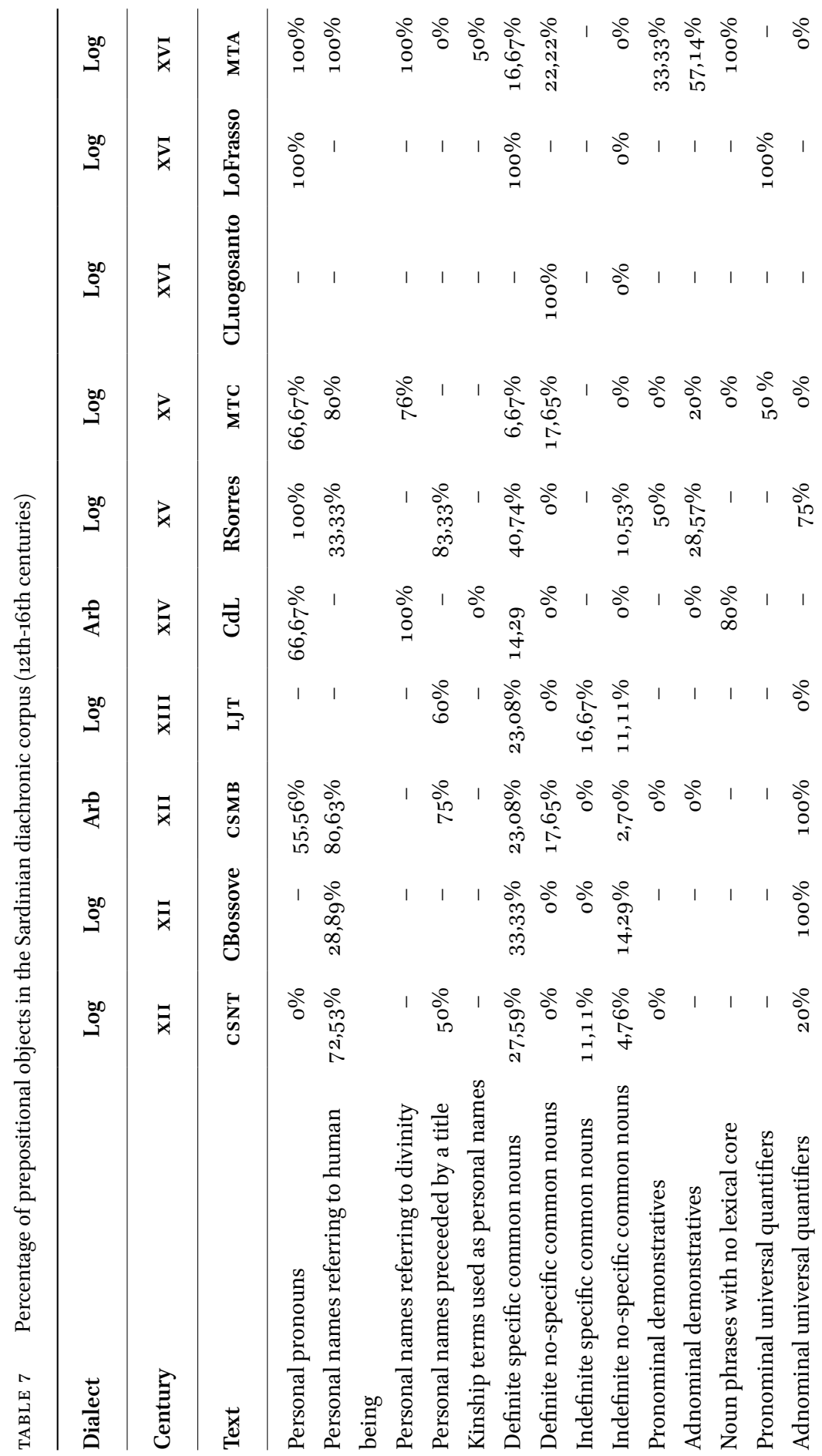




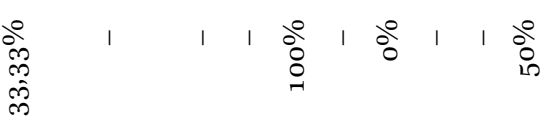

$\begin{array}{llllllllllll}1 & 0 & 0 & 1 & 1 & 1 & 1 & 1 & 1 & 1 & 1 & 1\end{array}$

\begin{tabular}{llllllllll}
1 & 1 & 1 & 1 & 1 & 1 & 0 & 0 & 1 & 0 \\
\hline & 1 & & 0 & 0
\end{tabular}

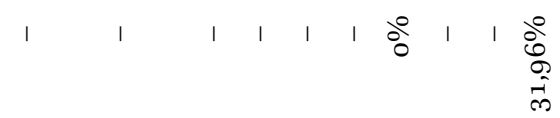

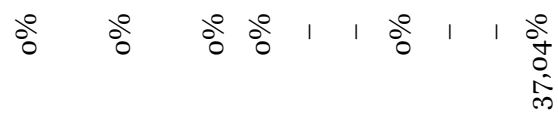

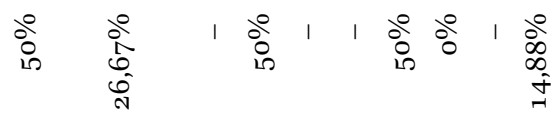

| $\begin{array}{lllllll}0 & 0 & 0 & 0 \\ 0 & & 0\end{array}$

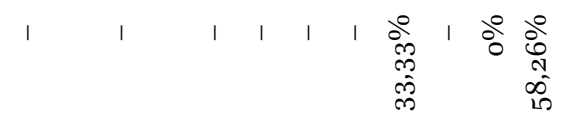

$\begin{array}{llllllllll}1 & 1 & 1 & 1 & 1 & 1 & 1 & 1 & 1 & 0 \\ 1 & & & & & & & & 0 \\ 0 & 0 \\ 0\end{array}$

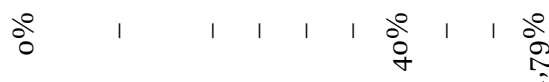

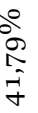

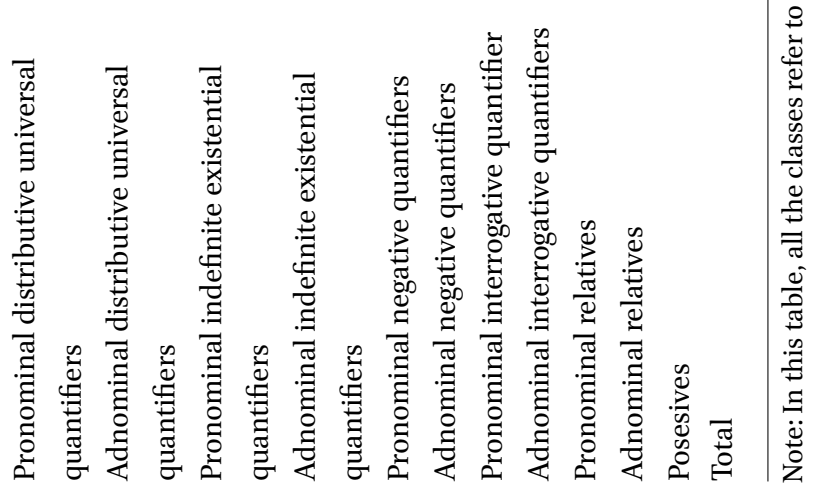




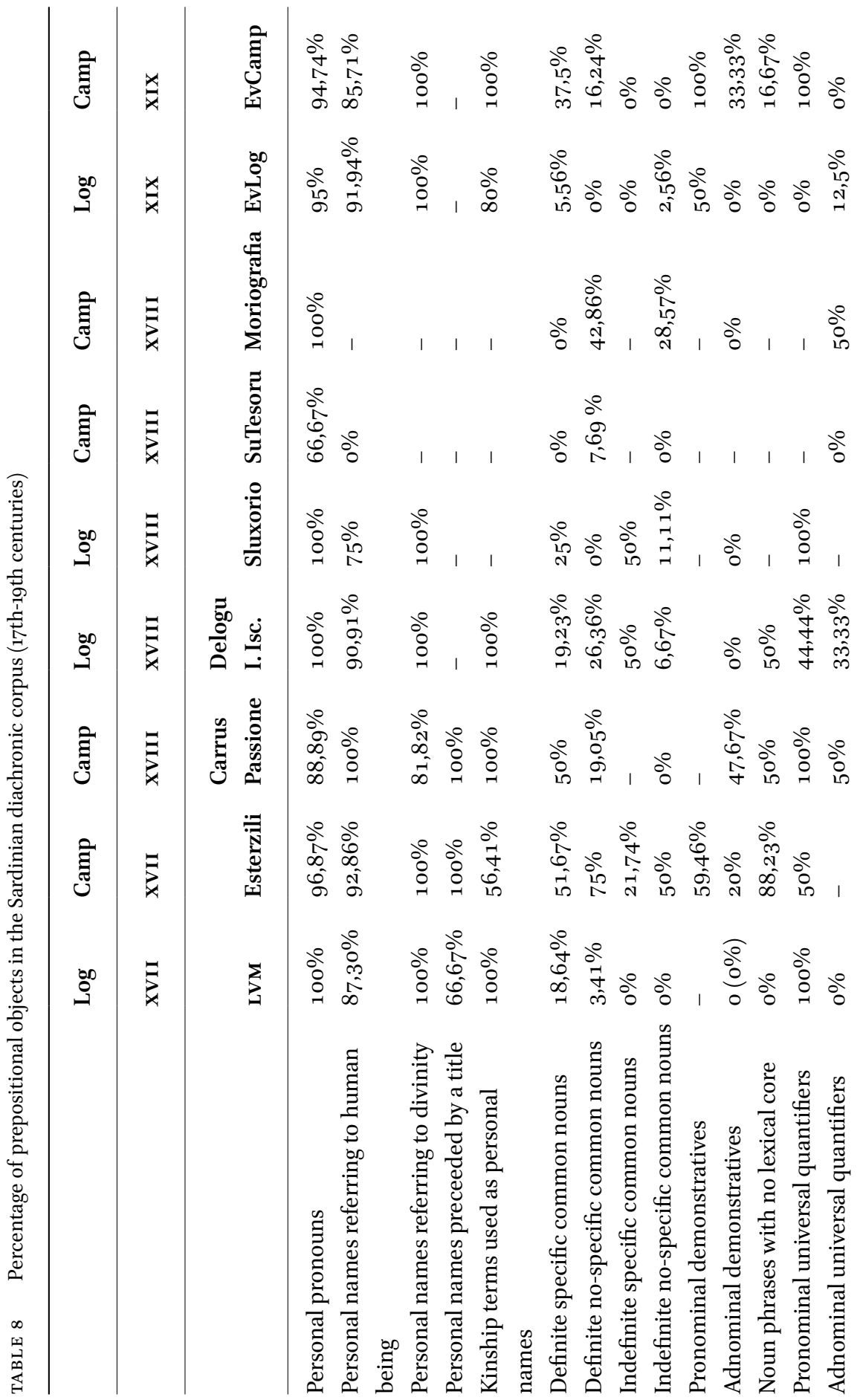




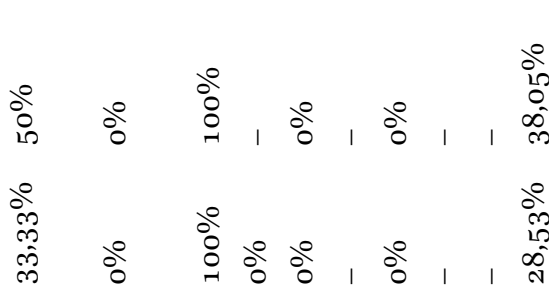

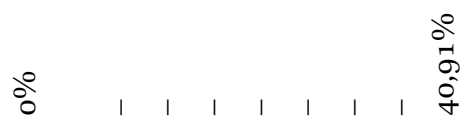

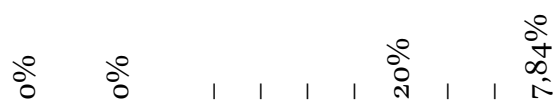

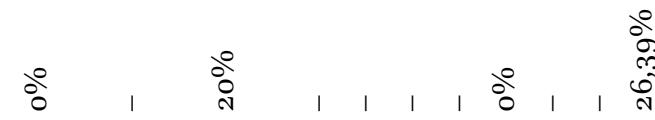

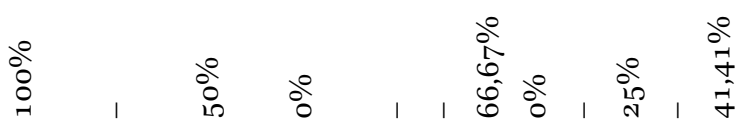

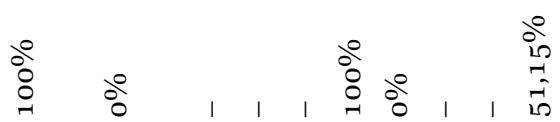

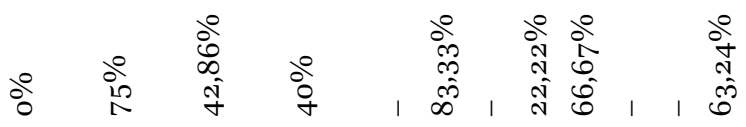

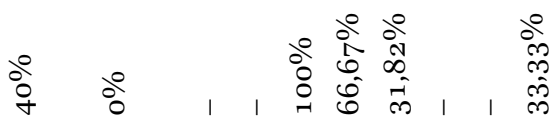

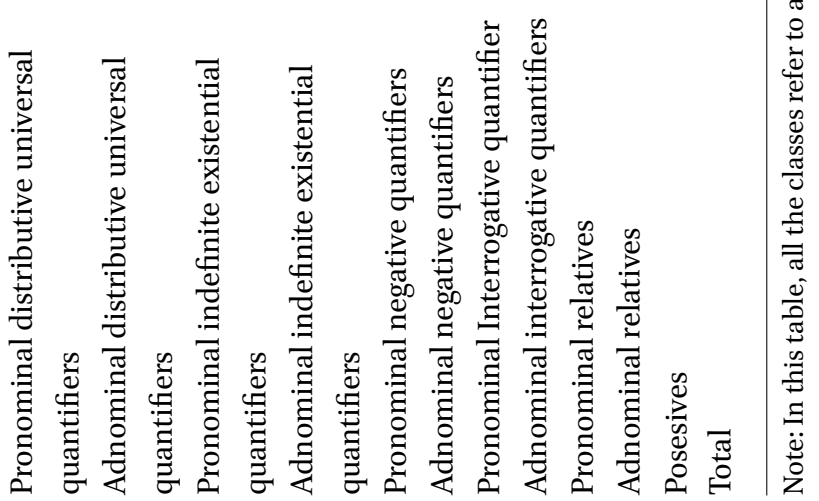


DOM as it appears in the previous diachronic development of this language (in Section 3), as well as according to the results of the analysis of the oral corpus of contemporary Arborense (in Section 4), however, there is room for positing an alternative view of the variation in the use of the preposition with object NPs in modern Sardinian. The position defended in this paper is that these oscillations are not an effect of the influence of Standard Italian but may be an inherent feature of the Sardinian Dом. This idea is elaborated in the following two points. First, the use of prepositional accusative in Arborense is pretty much the same as it appears in the diachronic corpus from the 16th to the 19th centuries, and in the two cases there is variability in the domains of both personal names and common animate nouns. This point has been dealt with in Sections 3 and 4 above and has been illustrated in examples (8) to (16). In other words, the referred variability can be observed not only in present day Sardinian, but it is also a feature which characterizes the Sardinian DOM during the diachronic development of this language. In addition, the Arborense use of prepositional accusative with definite common nouns (and sometimes with personal names too) depends mainly on contextual factors, as illustrated in examples (8) - (16) in Section 4 above. One gets the impression that the Sardinian prepositional accusative has maintained over the centuries a situation of constant or consistent instability and both in ancient Sardinian texts and in contemporaneous use, the preposition is used with a high degree of flexibility with the common animate nouns. With respect to object NPs which admit but not always show preposition, the fact that in some cases the preposition appears with highly specific objects in the clausal context suggests that the construction has a considerable vitality, in the sense that the distribution of the preposition with common nouns largely depends on the choice of the speakers.

Second, it should be taken into account that in the language contact scenario of Sardinian not only Standard Italian (with a very limited use of PREP. ACC.) but also Regional Italian (with a widespread use of prepositional accusative) have played and most probably still play a role. Although the influence of Standard Italian cannot be completely excluded, especially in bilingual educated speakers and with respect to the oscillations of use of the prepositional accusative with personal names, however, this kind of influence is not relevant for all Sardinian speakers and for this reason it cannot be considered a very relevant cause of use variation.

In sum, variability is a fairly constant feature of Sardinian DOM during the history of this language, which partially at least depends on the choice of the speaker, on the one hand, and a more realistic picture of the situation of diglossia in present day Sardinia involves the consideration of a Regional 
variety of Italian which is precisely characterized by the use of ром, on the other. The conjoined consideration of these points provide a solid basis to put into doubt the idea that the variability in the use of the prepositional accusative in Sardinian is merely an effect of Standard Italian influence. The coincidence in the variability observed in the historical corpus and in Contemporary Arborense points rather to the idea that it may well be an inherent feature of the Sardinian language ${ }^{11}$.

\section{7}

\section{Conclusions}

The main points of this paper are the following. First, in contemporary Arborense the prepositional accusative has a limited diffusion: though it is considered obligatory before personal names and pronominal quantifiers, in the actual use it is occasionally omitted. Similarly, the preposition can appear before all animate nominals provided that they are specific, but in practice, within the set of cases where it would be considered acceptable, it applies only in very highly referential NPs. Second, the limits of the three domains of distribution of the preposition which can be observed in the Arborense data are different to the descriptions of ром in Campidanian, Logudorian and Nuorese.

Arborense shows a low degree of variation with personal names, whereas this type of NP is always considered part of the obligatory domain in other varieties of Sardinian.

Third, for animate common nouns, the Sardinian prepositional accusative shows a certain degree of vitality and it has extensive flexibility: in these cases, the preposition can be used as a device to mark the high specificity of the object and its use largely depends on the speaker. Fourth, the flexibility in the contemporary use coincides with the results of the diachronic study conducted by the author: indeed synchronic variation displayed by Arborense prepositional accusative replicates the 'constant instability' which characterizes historical data.

11 An anonymous reviewer suggests that 'since the regional variety of Italian is used by speakers with little or no knowledge of Sardinian, it is at least conceivable that it might lead to an extension of ром or a destabilisation of the Dом system in Sardinian proper. Impressionistically, speakers of regional Italian may have a strong tendency to insert the preposition $a$ before direct objects of certain types, but under conditions which may be indeterminate or different from those which apply in Sardinian (e.g. before all NPs with human reference). In turn, this indeterminacy might transfer to Sardinian proper examples with a marked indefinite specific human object may be cases of this sort'. 
Fifth, in the language contact scenario both Standard and Regional Italian must be taken into account. Whereas the former has a very limited prepositional accusative (only dislocated personal pronouns), the latter shows a robust prepositional accusative system parallel to that of the Sardinian dialects. This does not mean that the presence of Dом in Sardinian Regional Italian precludes the possibility of any contact effect between Standard Italian and Sardinian. Rather, the presence of ром in Regional Italian makes the contact situation more complex: on the one hand, there is the Standard Italian, with a very reduced Dом system; on the other, there is the Regional Italian, with a DOM system similar to the Sardinian DOM system. Since all Sardinian speakers are also Regional Italian speakers, we could consider a double influence on Sardinian. The Standard Italian could influence Sardinian in the sense of a diminution of DOM, whereas the influence of the Regional Italian on Sardinian could result in a maintenance of DoM. However, diachronic data suggest us another interpretation of the variability of contemporary Sardinian Dом: the affinity, in the sense of the variability, between the data of the diachronic corpus and synchronic data speak for the idea that the variability of prepositional accusative could not be due to an external Italian influence, but it is rather an inherent feature of the Sardinian phenomenon.

\section{Acknowledgements}

I thank the three anonymous reviewers who motivated me to articulate some of my points more clearly and gave me the constructive comments which helped to improve this article. Furthermore I thank the participants of the Paris Workshop on Differential Object Marking and Language Contact for their comments. I am grateful to the Sardinian Region for giving financial support to part of the investigation included in the paper. A special thanks go to Carlos Garcia Castillero for his constant and invaluable supervision and for the very helpful discussions we had. Any remaining errors and inaccuracies are my own.

\section{References}

Berretta, Monica. 1989. Sulla presenza dell'accusativo preposizionale in italiano settentrionale: note tipologiche. Vox Romanica 48: 13-37.

Blasco Ferrer, Eduardo. 1998. Le parlate dell'Alta Ogliastra. Analisi dialettologica: saggio di storia linguistica e culturale. Cagliari: Della Torre. 
Blasco Ferrer, Eduardo and Giorgia Ingrassia. 2010. Sardo e lingue romanze a confronto: nuove prospettive per la genesi dell'accusativo preposizionale. In Maria Iliescu, Heidi Siller-Runggaldier and Paul Danler (eds.), Actes du xxve Congrès International de Linguistique et de Philologie Romanes, 145-158. Berlin and New York: De Gruyter.

Boeddu, Daniela. 2017. Estudio diacrónico del acusativo preposicional sardo, , Universidad del País Vasco - Euskal Herriko Unibertsitatea.

Bolognesi, Roberto. 2001. Il sardo tra isolamento e contatto: una rianalisi di alcuni stereotipi. Downloadable at http://www.romaniaminor.net/ianua/index2_en .htm.

Bolognesi, Roberto and Wilbert Heeringa. 2005. Sardegna fra tante lingue. Il contatto linguistico in Sardegna dal Medioevo ad oggi. Cagliari: Condaghes.

Dettori, Antonietta. 1993. Sardegna. In Luca Serianni and Paolo Trifone (eds.), Storia della lingua italiana, III: le altre lingue, Torino: Einaudi.

Dettori, Antonietta. 1998. La Sardegna. In Luigi Berlinguer and Antonello Mattone, Storia d'Italia: le regioni dall'unità a oggi, Torino: Einaudi.

Dettori, Antonietta. 2003. La Sardegna. In Manlio Cortelazzo (ed.), I Dialetti Italiani: storia, struttura e uso, Torino: Utet.

Jones, Michael Allan. 1993. Sardinian Syntax. London: Routledge.

Jones, Michael Allan. 1995. The prepositional accusative in Sardinian: its distribution and syntactic repercussions. In John Charles Smith and Martin Maiden (eds.), Linguistic Theory and the Romance Languages, 37-75. Amsterdam and Philadelphia: Benjamins.

Jones, Michael Allan. 1999. The pronoun determiner debate: evidence from Sardinian and repercussions for French. In Esthela Treviño and José Lema (eds.) Semantic Issues in Romance Syntax vol. 157: Theoretical Analyses on Romance Languages: Selected papers from the 26th Linguistic Symposium on Romance Languages (LSRL XXVI), Mexico City, 28 zo March, 1996, 121-140. John Benjamins Publishing.

Floricic, Franck. 2003. Notes sur l'accusatif prépositionnel en sarde. Bulletin de la Société linguistique de Paris: $247-303$.

Iemmolo, Giorgio. 2010. Topicality and differential object marking: evidence from Romance and beyond. Studies in language 34 (2): 239-272.

Lambrecht, Knud. 2001. Dislocation. In Martin Haspelmath, Ekkehard König, Wulf Oesterreicher and Wolfgang Raible (eds.), Language Typology and Language Universals: An International Handbook. (Handbücher zur Sprach-und Kommunikationswissenschaft, 20). Vol. 2., Berlin, New York: Walter de Gruyter. 1050-1078.

Lambrecht, Knud. 1994. Information structure and sentence form. A theory of topic, focus, and the mental representations of discourse referents. Cambridge: Cambridge University Press. 
Loi Corvetto. Ines. 1983. L'italiano Regionale di Sardegna. Bologna: Zanichelli.

Mardale, Alexandru. 2008. Microvariation within differential object marking. Revue roumaine de linguistique 53.4: 448-467.

Mardale, Alexandru. 2010. Éléments d'analyse du marquage différentiel de l'objet dans les langues romanes. Faits de Langues. Les Cahiers 2: 161-197.

Oppo, Anna (ed.). 2007. Le lingue dei sardi: una ricerca sociolinguistica. Rapporto finale, Regione Autonoma della Sardegna.

Putzu, Ignazio. 2005. L'accusativo preposizionale in sardo campidanese. In Antonietta Dettori (ed.), Quaderni del Dipartimento di Linguistica e Stilistica dell'Università di Cagliari. Lingue e culture in contatto, 225-260. Roma: Carocci.

Putzu, Ignazio. 2005a. Introduction. Sprachtypologie und Universalienforschung (sTUF) 58.2/3: 151-162.

Putzu, Ignazio. 2008. Per uno studio dell'accusativo preposizionale in sardo antico. In Romano Lazzeroni, Emanuele Banfi, Giuliano Bernini, Marina Chini and Giovanna Marotta (eds.), Diachronica et synchronica: studi in onore di Anna Giacalone Ramat, 397-428. Pisa: ETs.

Thomason, Sarah Grey and Terrence Kaufman. 1988. Language Contact, Creolization, and Genetic Linguistics. Berkeley: University of California Press.

Virdis, Maurizio. 1988. Sardo: aree linguistiche. In Günter Holtus, Michael Metzeltin and Christian Schmitt (eds.), Lexicon der romanistischen Linguistik, 897-913. Tübingen: Niemeyer.

Wagner, Max Leopold. 1922. Los elementos español y catalán en los dialectos sardos. Revista de Filología Española 9: 221-265.

\section{Abbreviations}

Arb. : Arborense

Camp.: Campidanian

Log.: Logudorian

Nuor.: Nuorese

\section{Contemporary Arborense Abbreviations and References}

Arca: Arca, Raffaele. 2011. Ammentande sos tempos. Cagliari: Condaghes. Frau: Frau, Costantina. 2007. Sos de Prte Tzier. Cagliari: Condaghes. 


\section{Diachronic Corpus Abbreviations and References}

CarrusPassione: Carrus, Maurizio. 1881. Sa passione et morte de nostru Signore Jesu Cristo, segundu sos battor evangelistas: comedia. Firenze: Tip. del Vocabolario.

CBossove: Meloni, Giuseppe and Andrea Dessì Fulgheri (eds.). 1994. Condaghe di San Leonardo di Bossove. Napoli: Liguori.

CdL: Lupinu, Giovanni (ed.). 2010. Carta de Logu dell'Arborea: nuova edizione critica secondo il manoscritto di Cagliari. Oristano: S'Alvure.

CLuogosanto: Fois, Graziano and Mauro Maxia (eds.). 20og. Il Condaghe di Luogosanto. Olbia: Editrice Taphros.

csmb: Virdis, Maurizio (ed.). 2003. Il condaghe di Santa Maria di Bonarcado. Nuoro: Ilisso.

CSNT: Merci, Paolo (ed). 2001. Il condaghe di San Nicola di Trullas. Nuoro: Ilisso.

DeloguIbbaIsc: Marci Giuseppe (ed.). 2003. Giovanni Delogu Ibba. Index Libri Vitae. Cagliari: CUEC.

Esterzili: De Martini, A. Luca (ed.). 2006. Libro de commedia di frate Antonio Maria da Esterzili. Cagliari: CUEc.

EvCamp: Petrovszki Lajszki, Brigitta and Giovanni Lupinu (ed.), 2004. Il Vangelo di San Matteo voltato in logudorese e cagliaritano: le traduzioni ottocentesche di Giovanni Spano e Federigo Abis. Il Vangelo di San Matteo in campidanese. Cagliari: CUEC).

EvLog: Petrovszki Lajszki, Brigitta and Giovanni Lupinu (eds.). 2004. Il Vangelo di San Matteo voltato in logudorese e cagliaritano: le traduzioni ottocentesche di Giovanni Spano e Federigo Abis. Il Vangelo di San Matteo in logudorese. Cagliari: cuEc.

LoFrasso: Spanu, Luigi. 1973. Antonio Lo Frasso, poeta e romanziere sardo-ispanico del Cinquencento. La battaglia di Lepanto; I milleduecento consigli; I dieci libri di fortuna d'amore: opere tradotte in lingua italiana. Sonetto sardo I, Sonetto sardo II, Glossa sarda XI. Cagliari: E. Gasperini.

LJT: Sanna, Antonio (ed.). 1957. Libellus Judicum Turritanorum. Cagliari: Edizioni S'Ischiglia.

LVM: Garippa, Ioan Mattheu. 1998. Legendariu de santas virgines, et martires de Jesu Christu. Nugoro: Papiros.

Moriografia: Marci, Giuseppe (ed.). 2002. Giuseppe Cossu. La coltivazione de' gelsi, e propagazione de' filugelli in Sardegna. Moriografia. Cagliari: cuec.

мTA: Pinna, Michele (ed.). 200o. Girolamo Araolla. Sa vida, su martiriu, et morte dessos gloriosos martires Gavinu, Brothu, et Gianuari. Sassari: Il Rosello.

мтC: Manca, Dino (ed.). 2002. Antonio Cano. Sa vitta et sa morte, et passione de sanctu Gavinu, Prothu et Januariu. Cagliari: cuec. 
RSorres: Piras, Sara Silvia and Gisa Dessì, (eds.). 2003. Il Registro di San Pietro di Sorres. Cagliari: cuec.

SLuxorio: Chessa Cappay, Gian Pietro. Historia de la vida y hechos de San Luxorio.

SuTesoru: Giuseppe Marci (ed.). 2004. Antonio Purqueddu. De Su Tesoru de sa Sardigna. Cagliari: CUEc. 